\title{
Apakah Transfer Tunai Pemerintah Memperburuk Modal Sosial? Kasus di Indonesia
}

\author{
Bayu Kharisma
}

Departemen Ilmu Ekonomi, Fakultas Ekonomi dan Bisnis, Universitas Padjadjaran

Jl. Dipati Ukur No. 35 Bandung, 40132, Indonesia

\begin{abstract}
ABSTRAK
Tujuan penelitian ini adalah mengevaluasi dampak kebijakan pemerintah dalam bentuk tunai terhadap modal sosial di Indonesia. Metode yang akan digunakan dalam penelitian ini adalah differences-indifferences (DID), sedangkan data yang digunakan adalah Indonesia Familiy Life Survey tahun 2000 dan 2007. Berdasarkan hasil estimasi menunjukkan bahwa rumah tangga penerima bantuan tunai tidak bersyarat yaitu Bantuan Langsung Tunai (BLT) lebih aktif terlibat dalam modal sosial, terutama dalam kegiatan arisan. Salah satu motivasi rumah tangga mengikuti partisipasi kegiatan arisan antara lain adalah untuk memiliki akses kredit dan kemampuan untuk mempertahankan daya beli atau melakukan consumption smoothing pada saat terjadi kenaikan harga bahan bakar minyak (BBM) di Indonesia. Sementara itu, rumah tangga penerima bantuan tunai tidak bersyarat yaitu Program Keluarga Harapan tidak berpengaruh secara statistik terhadap modal sosial di Indonesia. Temuan ini menunjukkan bahwa rumah tangga yang menerima bantuan Program Keluarga Harapan cenderung tidak aktif atau terlibat dalam kegiatan modal sosial di Indonesia.
\end{abstract}

Kata kunci: modal sosial (sosial capital), bantuan tunai (cash transfer), differences-in-differences, Indonesia Familiy Life Survey (IFLS)

Klasifikasi JEL: I38, O16, O17

\section{Does Government Cash Transfer Worse Social Capital? Case in Indonesia}

\begin{abstract}
This paper aims to evaluate the impact of government policies in cash transfer on social capital in Indonesia. The method that will be used in this study are differences-in-differences (DID), while the data used is Indonesia Familiy Life Survey in 2000 and 2007. Based on the estimation results, the recipient of cash assistance is unconditional, namely cash assistance (BLT) more actively involved in social capital, especially in arisan activities. One of the household motivations to participate in arisan activities is to have access to credit and the ability to maintain purchasing power or carry out consumption smoothing when there is an increase in the price of fuel oil (BBM) in Indonesia. Meanwhile, the households that received unconditional cash assistance, namely the Program Keluarga Harapan did not have a statistical effect on social capital in Indonesia. These findings indicate that households that receive Program Keluarga Harapan assistance tend to be less active or involved in social capital activities in Indonesia.
\end{abstract}

Keywords: social capital, cash transfer, differences-in-differences, Indonesia Familiy Life Survey (IFLS)

JEL classification: $138,016,017$

\section{PENDAHULUAN}

Modal sosial merupakan topik yang aktual dan menarik dalam kajian pembangunan ekonomi. Hal ini dikarenakan adanya klaim yang menyatakan bahwa perbedaan berbagai variabel sosial antar daerah maupun negara dapat menjelaskan adanya perbedaan pendapatan dan produktifitas yang muncul di daerah atau negara tersebut (Woolcock, 1998). Dalam hal ini, variabel non ekonomi yang dapat menangkap berbagai aspek dalam struktur sosial inilah yang disebut dengan modal sosial.

Para ahli telah menyadari pentingnya 
modal sosial dalam pembentukan masyarakat sipil (Fukuyama, 2000). Selain itu, keberadaan modal sosial juga penting tidak hanya sebagai penunjang efektivitas pemerintahan, namun memiliki kontribusi bagi pertumbuhan pendapatan serta indikator ekonomi lainnya (Keefer \& Knack, 2005). Pentingnya modal sosial sebagai elemen pokok dalam pembangunan seharusnya menjadi salah satu pertimbangan dalam pelaksanaan program pemerintah, termasuk bantuan tunai (cash transfer). Sejalan dengan mulai ditetapkan pelaksanaan program pemerintah tersebut, terutama dalam penanggulangan kemiskinan maka perhatian terhadap pengaruh modal sosial dari program tersebut mulai meningkat.

Salah satu program pemerintah dalam bentuk bantuan tunai adalah bantuan langsung tunai (BLT). Program tersebut ditetapkan sejalan dengan adanya kenaikan harga minyak dunia pada tahun 2005 yang mencapai tingkat tertinggi selama kurun waktu 25 tahun terakhir, yaitu sekitar $\$ 70$ per barel telah memaksa Pemerintah melakukan pengurangan subsidi untuk Bahan Bakar Minyak (BBM) sebanyak 2 kali pada Maret dan Oktober (Bank Indonesia, 2005).

Konsekuensi logis sebagai akibat pengurangan subsidi BBM tersebut maka harga BBM dalam negeri mengalami kenaikan. Dengan demikian, upaya untuk mengurangi dampak buruk kenaikan harga BBM tersebut maka Pemerintah menetapkan bantuan tunai langsung (BLT) yang dirancang untuk mengurangi beban masyarakat, khususnya masyarakat miskin untuk mempertahankan daya belinya pada saat pemerintah melakukan penyesuaian harga Bahan Bakar Minyak bersubsidi.

Bantuan tunai lainnya yaitu Program KeluargaHarapan(PKH). Program ini dilaksanakan dalam rangka percepatan penanggulangan kemiskinan dan juga sekaligus sebagai pengembangan kebijakan di bidang perlindungan sosial. PKH bukan merupakan kelanjutan program Bantuan Langsung Tunai (BLT) yang diberikan dalam rangka membantu rumah tangga miskin mempertahankan daya belinya pada saat pemerintah melakukan penyesuaian harga Bahan Bakar Minyak bersubsidi. PKH lebih dimaksudkan sebagai upaya membangun sistem perlindungan sosial kepada masyarakat miskin.

Salah satu isu krusial mengenai bantuan tunai yang ditetapkan oleh Pemerintah terhadap modal sosial adalah mewaspadai adanya potensi dampak yang tidak terukur dalam mekanisme penargetan pada ikatan dan hubungan sosial ditingkat komunitas (Hossain et al, 2010). Dalam jangka pendek, program bantuan tunai dengan penargetan mungkin tidak akan mengakibatkan dampak negatif yang berkelanjutan terhadap jalinan sosial yang ada. Namun, dalam jangka panjang akumulasi skema-skema bantuan melalui penargetan dapat memperdalam terjadinya perpecahan sosial karena individu mulai individualistik dan egoistik (Forde et al, 2011). Hal ini dapat beresiko terhadap melemahnya modal sosial yang ada dalam komunitas yang ditunjukkan oleh semakin rendahnya tingkat partisipasi masyarakat dalam kegiatan formal maupun tidak formal.

Beberapa studi mengenai pentingnya modal sosial sebagai determinan perkembangan ekonomi suatu masyarakat telah banyak dilakukan diberbagai negara berkembang dengan melibatkan teknik estimasi yang beragam. Babajanian (2012) menunjukkan bahwa bantuan tunai dapat mencegah anggota rumah tangga untuk pindah ke tempat lain, mempertahankan ikatan keluarga dan komunitas yang menyebabkan semakin aktifnya anggota rumah tangga dalam aksi sosial dan acara seremonial dalam suatu komunitas. Hidrobo et al, (2012) mengidentifikasi bahwa transfer pemerintah berkorelasi negatif dengan diskriminasi dan berhubungan positif dengan partisipasi masyarakat. Ressler (2008) menemukan bukti bahwa adanya transfer pemerintah dapat memperkuat jaringan sosial melalui penguatan modal sosial yang ditunjukkan oleh semakin tingginya tingkat partisipasi masyarakat dalam kegiatan formal dan tidak formal. Cameron dan Shah (2012) mengindikasikan bahwa kesalahan target dalam BLT terutama adanya kebocoran, berhubungan positif terhadap peningkatan kriminalitas yang dialami rumah tangga. Selain itu, mengkonfirmasi bahwa adanya kebocoran BLT berkorelasi negatif dengan partisipasi anggota rumah tangga dalam kegiatan kemasyarakatan.

Kajian yang terkait dampak transfer pemerintah terhadap modal sosial selama ini memiliki indikator dan hasil estimasi yang cukup beragam. Pertama, salah satu indikator yang digunakan adalah aktivitas individu atau rumah tangga dalam kegiatan kemasyarakatan. Dalam masyarakat dengan intensitas sosial 
yang beranekaragam, jenis kegiatan sosial yang dilakukan sangat bervariasi dan bersifat unik antar komunitas. Kedua, adalah keputusan rumah tangga untuk terlibat dalam kegiatan sosial yang didasarkan oleh faktor-faktor yang sulit untuk diukur secara empiris. Dalam hal ini, kegiatan sosial lebih banyak dipengaruhi oleh kesadaran individu atas tanggung jawab menjaga keamanan dan kenyamanan lingkungan dan tidak ada sanksi hukum yang mengikat seseorang untuk terlibat dalam kegiatan sosial. Rumah tangga dengan tingkat kesadaran sosial yang tinggi akan terlibat aktif dalam kegiatan masyarakat. Sebaliknya, rumah tangga yang relatif individualistik dan egoistik cenderung untuk menghindari aktivitas kegiatan kemasyarakatan. Ketiga, masalah estimasi dalam kajian tersebut dapat diatasi jika tersedia data yang cukup informatif mengenai keterlibatan anggota rumah tangga dalam berbagai kegiatan masyarakat. Dengan demikian, tujuan penelitian ini adalah untuk mengetahui faktorfaktor yang menentukan keterlibatan rumah tangga dalam modal sosial di Indonesia dan mengevaluasi dampak kebijakan pemerintah dalam bentuk tunai (cash transfer) terhadap modal sosial di Indonesia.

Penelitian ini memberikan kontribusi penting secara empiris, antara lain: pertama, melakukan analisis transfer tunai pemerintah, baik yang bersifat bersyarat maupun tidak bersyarat dengan menggunakan keterlibatan partisipasi masyarakat sebagai indikator modal sosial secara lebihterperincidankomprehensif.Kedua,Indonesia Family Life Survey (IFLS) memiliki struktur panel yang sangat diperlukan untuk menerapkan metode yang relevan untuk mengontrol faktor-faktor penting yang tidak dapat terobservasi (unobserved heterogeneity). Sebagai ilustrasi, rumah tangga yang cenderung egoistik atau individualistik cenderung tidak berperan aktif dalam kegiatan kemasyarakatan. Oleh karena itu, tanpa mengontrol unobserved heterogeneity tersebut maka estimasi koefisien regresi antara variabel utama (interest variable) dengan berbagai indikator partisipasi masyarakat akan berpotensi bias. Selain itu, jenis data mikro IFLS dengan struktur panel memiliki informasi yang komprehensif mengenai kegiatan kemasyarakatan dan program transfer pemerintah tunai (cash transfer) di Indonesia seperti Bantuan Langsung Tunai (BLT) dan Program Bantuan Tunai Bersyarat yaitu Keluarga Harapan.

\section{TINJAUAN LITERATUR \\ Pendekatan Ekonomi dalam Modal Sosial}

Pada bagian ini, akan dijelaskan model investasi mengenai modal sosial yang telah dikembangkan sebelumnya (Glaeser, Laibson \& Sacerdote, 2001). Model ini hampir identik dengan model standar investasi dalam modal fisik dan manusia. Dengan pendekatan individual terhadap modal sosial akan dimulai dengan dengan permasalahan investasi sederhana. Modal sosial individu diwakili sebagai variabel stok, $\mathrm{S}$, dan modal sosial perkapita agregat diwakili sebagai variabel stock, $\hat{s}$. Masing-masing individu menerima aliran utilitas per periode $\mathrm{S}^{*} \mathrm{R}(\hat{s})$, di mana $\mathrm{R}(\hat{s})$ adalah fungsi yang dapat diferensialkan dengan modal sosial per kapita agregat sebagai argumennya.

Hasil arus $\mathrm{S} * \mathrm{R} \quad(\hat{s})$ mencerminkan pengembalian pasar (market return) dan bukan pasar. Tingkat pengembaliaan pasar dapat mencakup kenaikan upah atau prospek pekerjaan yang lebih baik bagi orang-orang yang kompeten secara sosial. Tingkat pengembalian non-pasar dapat mencakup perbaikan di masyarakat, kesehatan, atau bahkan kebahagiaan langsung. Literatur tentang modal sosial berpendapat bahwa adanya saling melengkapi secara positif dalam investasi modal sosial di seluruh individu, dimana tidak ada keuntungan yang diperoleh secara individu sehingga $\mathrm{R}$ ' $(\hat{s})>0$.

Stok modal sosial mengikuti batasan anggaran dinamis (dynamic budget comstraint), $S_{t+1}=\delta S_{t}+I$, di mana $S_{t}$ mewakili persediaan modal sosial yang telah terakumulasi dan $\delta$ adalah faktor penyusutan. Oleh karena itu, $1-\delta$ adalah tingkat depresiasi. Tingkat investasi, I, memiliki biaya waktu $\mathrm{C}\left(I_{t}\right)$, di mana $\mathrm{C}($.) cenderung meningkat dan memiliki bentuk cembung. Opportunity cost dari waktu adalah w, mewakili tingkat upah atau nilai waktu senggang jika pasokan tenaga kerja inelastis. Diasumsikan bahwa individu memiliki periode $\mathrm{T}$ umur yang diketahui dan mengabaikan masa depan dengan faktor diskonto, $\beta$. Selain itu, diasumsikan bahwa dengan probabilitas $\theta$ individu tersebut tinggal di komunitasnya. Pada saat orang bergerak, nilai modal sosial mereka secara diskresi terdepresiasi, turun berdasarkan faktor, $\lambda$ - Penurunan ini dimaksudkan untuk menangkap gagasan bahwa sebagian besar investasi modal sosial bersifat spesifik oleh masyarakat. Misalkan, 
$\phi=\theta+(1-\theta) \lambda$. Oleh karena itu, $\phi$ mewakili faktor penyusutan yang timbul dari mobilitas. Masalah maksimalisasi individu sekarang dapat dinyatakan sebagai:

$$
\begin{gathered}
\max _{I_{0}, I_{1}, \ldots, I_{T}} \sum_{t=0}^{T} \beta^{t}\left[S_{t} * R(\hat{S})-\mathbb{C}\left(I_{t}\right)\right] \\
\text { s.t } S_{t}=\boldsymbol{\phi} S_{t}+I_{t}, \forall t
\end{gathered}
$$

Persamaan yang menggambarkan evolusi persediaan modal menggabungkan depresiasi yang diharapkan yang timbul dari mobilitas. Individu memaksimalkan fungsi obyektifnya, mengambil modal sosial per kapita agregat, $\hat{s}$, sebagai kondisi yang tetap. Kondisi orde pertama yang terkait dengan masalah investasi ini diberikan oleh:

$$
\sqrt{C}{ }^{\prime}\left(I_{t}\right)=\frac{1-(\beta \delta \phi)^{T-t+1}}{1-\beta \delta \phi} R(\hat{S})
$$

Kondisi orde pertama (first order condition) ini menyiratkan hasil statis komparatif berikut ini. Investasi modal sosial (1) meningkat dengan faktor diskonto, $\beta$, (2) menurun dengan mobilitas, $\phi$, (3) menurun dengan opportunity cost waktu, $\mathrm{W}$, (4) meningkat dengan tingkat pengembalian pekerjaan terhadap keterampilan sosial, $\mathrm{R}($.$) (5)$ menurun dengan tingkat depresiasi, $(1-\beta)$, (6) meningkat di masyarakat dengan lebih banyak modal agregat, S, (7) meningkat ketika modal sosial kurang spesifik bagi masyarakat, $\phi$ dan (8) menurun seiring bertambahnya usia, $t$.

Selain itu, karena persediaan modal sosial adalah fungsi dari arus, semua kecuali salah satu statistik komparatif ini menetapkan persediaan modal sosial dan juga arus investasi ke modal sosial. Satu-satunya pengecualian adalah usia, dengan asumsi bahwa endownment modal sosial individu cukup rendah saat lahir. Pada awal siklus hidup individu akan terlibat dalam akumulasi modal sosial, namun menjelang akhir masa manfaat dari investasi akan nol dan tidak akan terjadi biaya (jika biaya positif). Oleh karena itu, keterlambatan dalam investasi hidup tidak akan mengimbangi penyusutan. Dengan demikian, akan mengharapkan profil modal sosial dengan puncak usia pertengahan.

Dua sifat khusus modal sosial cukup menonjol. Pertama, modal sosial cenderung tinggi pada komunitas yang spesifik. Dengan demikian, mobilitas residensial harus menjadi penentu utama investasi di modal sosial. Tentu saja ada paralel yang kuat dengan fokus Becker (1964) pada modal manusia spesifik perusahaan, yang secara tajam terdepresiasi ketika individu meninggalkan pekerjaan saat ini. Demikian juga, modal sosial akan terdepresiasi ketika individu meninggalkan komunitasnya. Secara alamiah, dalam model yang lebih lengkap, keputusan mobilitas itu sendiri akan bersifat endogen dan diperkirakan akan menurun sebagaimana individu mengakumulasi modal sosial dalam masyarakat tertentu. Kedua, modal sosial dianggap memiliki saling melengkapi antar individu. Hal ini mungkin benar untuk modal fisik dan manusia, tapi tidak ada tempat untuk melengkapi komplementaritas positif di antara orang-orang menjadi lebih kuat daripada dalam kasus modal sosial.

Komplementaritas ini menunjukkan bahwa mungkin ada multiplier sosial yang besar. Dengan kata lain, efek dari perubahan parameter untuk individu mungkin jauh lebih kecil daripada efek perubahan pada parameter yang sama untuk agregat. Hal ini sangat penting dalam mencoba memahami perubahan besar dalam tingkat modal sosial dari waktu ke waktu. Efek multiplier agregat ini akan sulit diukur dengan menggunakan analisis cross-sectional, karena tingkat agregat modal sosial adalah dengan definisi tetap konstan ketika variasi cross-sectional digunakan untuk mengidentifikasi efek empiris.

Selanjutnya, untuk membuat hal ini lebih konkret, persamaan (1) dimodifikasi sehingga $\mathrm{T}$ tidak terhingga dan memeriksa tingkat steady state dari modal sosial. Dalam steady state $I=(1-\delta) S$ , menyiratkan bahwa untuk perubahan upah individu (dengan menetapkan tingkat komunitas dari modal sosial konstan) maka persamaan (1) menjadi sebagai berikut.

$$
\frac{\partial S}{\partial w}=-\frac{\left.C^{\prime}(1-\delta) S\right)}{\left.(1-\delta) \mathbb{C}^{\prime \prime}(1-\delta) S\right)}
$$

Untuk perubahan upah secara agregat, kita dapat memikirkan kasus komunitas homogen dimana $\mathrm{S}=\hat{s}$. Pada kasus ini maka

$$
\frac{\partial S}{\partial w}=-\frac{\left.C^{\prime}(1-\delta) S\right)}{(1-\delta) \mathbb{C} \quad(1-\delta) S)-R^{\prime}(\hat{S})(1-\beta \delta \phi)}=\frac{1}{1-\frac{\partial S}{\partial \hat{\lambda}}} \frac{\partial S}{\partial w}
$$

dimana $\frac{1}{1-\frac{\partial S}{\partial \hat{S}}}$ adalah multiplier sosial.

Pada saat terjadi kenaikan pada modal sosial secara aggregat maka akan meningkatkan investasi 
individu dalam modal sosial maka kemungkinan elastisitas agregat modal sosial terhadap parameter apapun (dalam hal ini opportunity cost dari waktu) akan jauh lebih tinggi daripada elastisitas mikro modal sosial sehubungan dengan variabel yang sama.

Komplementaritas ini dapat meningkatkan kemungkinan bahwa ada beberapa ekuilibrium di tingkat investasi modal sosial. Dalam beberapa komunitas, tingkat investasi tinggi dan pengembalian investasi meningkat tinggi. Sementara itu, dalam komunitas lain, tidak ada yang berinvestasi dan tingkat pengembalian investasi rendah. Literatur tentang modal sosial sering menekankan pentingnya kondisi historis dalam menentukan tingkat modal sosial di sebuah komunitas (Putnam, 1993).

Dampak transfer pemerintah tunai, terutama yang bersyarat terhadap modal sosial dapat terjadi pada berbagai saluran (channel) yang berbeda. Salah satu saluran tersebut mengacu pada terpilihnya individu sebagai penerima manfaat program. Adanya seleksi cara yang ketat untuk menguji penargetan berpotensi untuk mengecualikan individu yang tampaknya serupa dari transfer. Oleh karena itu, akan mengikis kepercayaan interpersonal dan institusional serta memperkuat stigma sosial. Namun, pada saat bersamaan, hal itu juga bisa memberikan efek positif pada penerima manfaat melalui peningkatan harga diri (self-esteem). Kedua, mengacu pada pengaruh transfer pendapatan. Penerima transfer dapat mengurangi partisipasi angkatan kerja penerima manfaat tersebut sehingga membuat lebih rentan untuk terlibat dalam kegiatan sosial, namun berpotensi menghancurkan jaringan kerja. Pada saat bersamaan, jika usaha kerja penerima manfaat meningkat, sebagian dapat menarik diri dari kegiatan yang tidak terkait dengan pasar (non market). Hal ini juga dapat membuat penerima manfaat kurang bergantung pada jaringan atau komunitas masyarakat.

Selain itu, hal yang perlu diperhatikan mengenai dampak bantuan tunai Pemerintah terhadap modal sosial adalah mewaspadai adanya potensi dampak yang tidak terukur dalam mekanisme penargetan pada ikatan dan hubungan sosial pada tingkat komunitas (Hossain et al, 2010). Dalam jangka pendek, program bantuan tunai dengan penargetan mungkin tidak akan mengakibatkan dampak negatif yang berkelanjutan terhadap jalinan sosial yang ada. Namun, dalam jangka panjang akumulasi skema-skema bantuan melalui penargetan dapat memperdalam terjadinya perpecahan sosial karena individu mulai individualistik dan egoistik. Hal ini dapat beresiko terhadap melemahnya modal sosial yang ada dalam komunitas yang ditunjukkan oleh semakin rendahnya tingkat partisipasi masyarakat dalam kegiatan formal maupun tidak formal.

\section{PENELITIAN SEBELUMNYA}

Pentingya modal sosial sebagai determinan perkembangan ekonomi suatu masyarakat telah dibahas oleh beberapa peneliti. Secara konsep, modal sosial sering dikaitkan dengan nilai sosial yang berlaku dalam masyarakat, rasa saling percaya (trust) dan partisipasi individu atau rumah tangga dalam kegiatan atau organisasi kemasyarakatan, khususnya di pedesaan.

Beberapa studi empiris yang berkaitan dengan program pemerintah dan modal sosial menjadi hal menarik bagi para ekonom dan pembuat kebijakan karena melibatkan data, hasil empiris dan pendekatan yang berbeda. Secara empiris, para ahli telah memperkenalkan konsep perhitungan yang terkait dengan modal sosial mulai lingkup rumah tangga hingga level komunitas (Stone, 2001). Adato (2000) menunjukkan bahwa dampak progam pemerintah Progresa atau Oportunidades pada hubungan sosial tingkat masyarakat bukanlah fokus perhatian program, namun hasil penelitiannya menunjukkan bahwa program tersebut menciptakan ketegangan di dalam masyarakat antara penerima manfaat dan penerima manfaat non-program. Hal yang sama, Skoufias (2005) mengidentifikasi bahwa dampak program Progresa telah memperkenalkan perpecahan sosial di dalam masyarakat.

Hjoullund dan Svendsen (2000) secara khusus memperkenalkan metode perhitungan untuk membuat semacam indeks modal sosial menggunakan analisis faktor. Dalam hal ini, peneliti membatasi konsep modal sosial dalam dimensi percaya (trust), kerjasama dan jaringan sosial (social network). Secara umum, dimensi sosial dibagi dalam 2 indikator besar, yaitu indikator kepercayaan dan indikator sukarela dalam suatu kelompok. Dalam aspek kerjasama kelompok, peneliti menggunakan kriteria Putnam mengenai modal sosial yang dirumuskan sebagai jumlah keanggotaan dalam organisasi masyarakat. 
Keterkaitan antara modal sosial dengan pertumbuhan ekonomi secara aggregat dianalisa oleh Garcia, Martínez \& Radoselovics (2006). Menggunakan data time series 1970 sampai 2001 untuk 23 negara OECD peneliti menemukan adanya hubungan positif dan signifikan antara modal sosial dengan pertumbuhan ekonomi, Modal sosial menyumbang sebesar 7 sampai 10 persen pada pertumbuhan ekonomi negaranegara yang menjadi sampel. Temuan ini semakin mempertegas pentingnya kontribusi modal sosial dalam pertumbuhan ekonomi disamping faktorfaktor penjelas lainnya.

Penelitian lainnya yang terkait dengan modal sosial di Indonesia dilakukan oleh Grootaert (1999) dengan menggunakan data hasil survei local level institution di 3 propinsi di Indonesia yaitu Jambi, Jawa Tengah dan Nusa Tenggara Timur. Data yang digunakan terdiri atas multilevel, mulai dari rumah tangga, komunitas sampai distrik. Beberapa indikator modal sosial yang digunakan adalah density membership, heterogeneity indx, meeting attendance serta decision making index. Hasil penelitiannya menunjukkan bahwa rumah tangga dengan modal sosial yang lebih tinggi menikmati pengeluaran yang lebih tinggi, memiliki banyak aset, lebih banyak memiliki tabungan dan memiliki akses yang lebih tinggi terhadap kredit. Selain itu, peneliti juga menemukan mekanisme efek positif modal sosial terhadap indikator keesejahteraan melalui 3 jalur yaitu saling berbagi informasi antar anggota kelompok kegiatan, mengurangi perilaku oportunistik dan memperbaiki proses pembuatan kelompok masyarakat.

Evaluasi dampak transfer pemerintah dalam bentuk bantuan tunai telah banyak diteliti, termasuk pengaruh adanya kesalahan target penerima bantuan. Stoffler (2012) melakukan simulasi untuk menguji pengaruh transfer tunai terhadap konsumsi dan produksi rumah tangga petani menggunakan data rumah tangga di Taiwan. Hasil beberapa simulasi menunjukkan bahwa transfer memiliki dampak positif terhadap peningkatan konsumsi dan produksi. Pengaruh positif transfer tunai juga dirasakan oleh rumatangga bukan penerima (non target) dan rumah tangga penerima manfaat meski bukan rumah tangga miskin.

Terkait dengan adanya kesalahan target, Weiss (2004) mengidentifikasi bahwa fenomena tersebut merupakan hal lumrah terjadi di negara-negara berkembang yang telah lama menyelenggarakan program pengentasan kemiskinan seperti India dan Cina. Adanya leakage dan undercover juga ditemukan di negara yang relatif baru dalam melaksanakan program transfer pemerintah seperti Indonesia dan Thailand. Secara umum dapat disimpulkan bahwa meskipun terdapat kebocoran, program pengentasan kemiskinan membawa dampak positif terhadap kesejahteraan masyarakat.

Dalam ruang lingkup yang lebih luas, Coady et al (2004) melakukan review terhadap targeting program di negara-negara berkembang. Beberapa metode targeting dibahas secara detail dan dilakukan indeksasi untuk mengukur kinerja targeting di beberapa negara, termasuk Indonesia. Evaluasi dilakukan tidak hanya untuk program transfer, namun juga mencakup program subsidi dan program penciptaan lapangan kerja. Dampak transfer pemerintah tidak hanya dievaluasi pada indikator kesejahteraan rumah tangga seperti konsumsi, kesehatan dan pendidikan. Beberapa penelitian juga mengkaji dampak tidak langsung pemberian transfer pemerintah terhadap modal sosial.

Attanasio et al (2008) dengan pendekatan eksperimen mengidentifikasi bahwa tingkat kerjasama masyarakat yang mendapatkan program relatif lebih tinggi dibandingkan masyarakat yang tidak mendapatkan program. Sementara itu, Ressler (2008) dengan pendekatan kualitatif menemukan bukti bahwa adanya transfer pemerintah justru memperkuat jaringan sosial yang ada. Pengaruh tidak langsung kebijakan transfer pemerintah terhadap rumah tangga yang bukan penerima program didaerah yang menjadi obyek penelitian mengalami peningkatan. Angelucci \& Giorgi (2009) menemukan bukti bahwa adanya transfer pemerintah dapat meningkatkan konsumsi rumah tangga yang bukan pemerima sebesar 10 persen. Kenaikan tersebut terjadi melalui jalur peningkatan pinjaman, transfer yang bersifat pribadi (privat) antar keluarga dan terjadi penurunan tingkat tabungan rumah tangga.

Chong, Ñopo \& Ríos (2009) melalui bukti eksperimental menemukan bahwa program kesejahteraan dapat menghancurkan modal sosial yang diukur dengan kepercayaan interpersonal. Analisisnya didasarkan pada sampel acak di empat kota Amerika Latin (Bogotá, Lima, Montevideo dan San José). Hasil temuannya menunjukkan bahwa program kesejahteraan menghasilkan stigma 
dan pada gilirannya menciptakan eksternalitas yang diterjemahkan ke dalam kepercayaan dan penghancuran modal sosial.

Kumlin dan Rothstein (2005) menganalisis kasus Swedia yang menunjukkan hasil yang sesuai dengan Chong, Nopo \& Ríos (2009). Fokus utama penelitian ini adalah untuk memecahkan paradoks koeksistensi negara kesejahteraan yang kuat dan tingkat kepercayaan dan ketelitian yang tinggi: sesuai dengan analisis ekonomi standar, negara kesejahteraan yang kuat akan membuat orang kurang memperhatikan yang lain, asalkan Negara mengurus orang-orang miskin yang kekurangan dan miskin. Dalam analisisnya menunjukkan bahwa paradoks dapat dipecahkan saat mempertimbangkan jenis intervensi kesejahteraan yang terlibat. Padahal lembaga kesejahteraan universal cenderung menciptakan kepercayaan, berarti manfaat yang diuji menghancurkannya.

Berdasarkan hasil studi literatur menunjukkan adanya temuan kontradiktif antara berbagai program pemerintah, termasuk transfer tunai dengan modal sosial. Dalam beberapa studi menunjukkan bahwa peran program pemerintah dapat meningkatkan modal sosial. Namun, disisi lain memberikan hasil yang sebaliknya.

\section{METODOLOGI}

Model estimasi yang digunakan dalam penelitian ini adalah mengikuti model telah dilakukan sebelumnya (Bertrand, Duflo \& Mullainathan, 2004; Cameron \& Shah, 2011) dengan beberapa modfifikasi. Penelitian ini menggunakan teknik estimasi differences-indifferences (DID) untuk menganalisa dampak transfer tunai pemerintah terhadap modal sosial di Indonesia.

$s_{i j t}=\alpha_{0}+\alpha_{1}$ Transfer $_{t}+t_{t}+\delta$ Transfer $r_{i} * t_{t}+x_{i}+y_{f}+u_{i j t}$

dimana $s_{\text {ivt }}$ adalah variabel yang menggambarkan modal sosial $i$ pada komunitas $j$ pada tahun $t$. Variabel modal sosial dalam penelitian ini merujuk pada studi yang sebelumnya yaitu partisipasi rumah tangga dalam kegiatan masyarakat di pedesaan (Putnam, 1993 ; Gertler, Levine \& Moretti, 2006 ; Attanasio, Reyes \& Pellerano, 2015). Partisipasi rumah tangga tersebut meliputi : partisipasi dalam kegiatan arisan, pertemuan warga atau masyarakat, koperasi (semua jenis koperasi dan di semua tingkat: desa wisma, RT, RW, desa/kelurahan, kecamatan), kegiatan kelompok pemuda (karang taruna), kegiatan siskamling, kerja bakti rutin (jumat bersih, bersih desa), program perbaikan kampung (KIP, MHT, konblokisasi, perbaikan jalan, membangun fasilitas umum) dan Pembinaan Kesejahteraan Keluarga (PKK). $\mathrm{x}$ adalah vektor karateristik rumah tangga, y adalah vektor karateristik desa. Transfer adalah bantuan tunai dari pemerintah yaitu Bantuan Langsung Tunai (BLT) dan Program Keluarga Harapan (PKH). Sementara itu, $\mathrm{t}$ adalah dummy variabel periode waktu dimana $1=$ tahun 2007 dan $0=$ tahun 2000, sedangkan $\mathrm{u}_{\mathrm{ijt}}$ ialah term term.

Pada persamaan (3) di atas yang menjadi perhatian yaitu adanya variabel-variabel tidak teramati (unobserved) bersifat time invariant yang dapatmempengaruhimodal sosial danimplementasi transfer tunai (BLT dan PKH) sehingga dapat menyebabkan bias. Misalnya, seorang kepala desa yang tidak berkompeten secara administratif dalam menyalurkan bantuan BLT dan PKH dapat mempengaruhi keputusannya untuk menentukan yang berhak dan tidak untuk menerima bantuan tunai dari pemerintah. Selain itu, adanya perbedaan faktor geografis antar desa, preferensi rumah tangga yang kurang bersosialisasi cenderung tidak aktif dalam kegiatan kemasyarakatan di desa dan luput dari pembagian bantuan tunai pemerintah. Dengan demikian, untuk mengontrol unobserved charateristics tersebut maka dilakukan metode fixed effects pada tingkat desa sehingga masalah bias dapat diatasi. Oleh karena itu, melalui metode fixed effects pada tingkat desa maka persamaan (3) menjadi sebagai berikut :

$$
s_{i j t}=\alpha_{0}+\alpha_{1} \text { Transfer }_{i}+t_{t}+\delta \text { Transfer }_{i} * t_{t}+x_{i}+y_{j}+\pi_{j}+u_{i j t}
$$

\subsection{Deskripsi Data}

Data yang digunakan dalam tulisan ini adalah publikasi dari Indonesia Family Life Survey (IFLS) atau Survai Aspek Kehidupan Rumah Tangga Indonesia (SAKERTI) gelombang ke-3 (tahun 2000) dan IFLS gelombang ke-4 (tahun 2007). Data tersebut digunakan untuk menangkap periode sebelum dan sesudah diberlakukan program transfer tunai tidak bersyarat (Bantuan Langsung Tunai) dan bantuan tunai tidak bersyarat (Program Keluarga Harapan) terhadap kegiatan partisipasi masyarakat. Pada IFLS gelombang ke 4 (tahun 2007) tersedia secara khusus, beberapa pertanyaan mengenai program pemerintah berkaitan dengan bantuan tunai yang diterima oleh rumah tangga melalui program kompensasi pengurangan subsidi BBM yaitu Bantuan Langsung Tunai (BLT) dan Program Bantuan Tunai Bersyarat (Keluarga 
Tabel 1.

Statistik Deskriptif Beberapa Karateristik

Rumahtangga dan Desa Periode Tahun 2000-2007

\begin{tabular}{|c|c|c|}
\hline Variabel & Mean & Std. Dev. \\
\hline Bantuan Langsung Tunai $($ ya $=1)$ & 0.152 & 0.359 \\
\hline Program Keluarga Harapan $($ ya $=1)$ & 0.001 & 0.034 \\
\hline \multicolumn{3}{|l|}{ Pendidikan Kepala Rumah tangga } \\
\hline Tidak Sekolah $($ ya $=1)$ & 0.142 & 0.349 \\
\hline Sekolah Dasar $(\mathrm{ya}=1)$ & 0.525 & 0.499 \\
\hline Sekolah Menengah Pertama $($ ya $=1)$ & 0.128 & 0.335 \\
\hline Sekolah Menengah Atas $($ ya $=1)$ & 0.141 & 0.348 \\
\hline Universitas $(\mathrm{ya}=1)$ & 0.054 & 0.226 \\
\hline Jumlah Anggota Keluarga & 4.200 & 1.929 \\
\hline Jumlah Anggota Keluarga Kuadrat & 21.360 & 19.977 \\
\hline Jenis Kelamin Kepala Rumah tangga (perempuan $=1$ ) & 0.187 & 0.390 \\
\hline Status Kepala Rumah tangga $($ menikah $=1)$ & 0.810 & 0.392 \\
\hline Kepala Rumah tangga tidak bekerja $($ ya $=1)$ & 0.129 & 0.336 \\
\hline \multicolumn{3}{|l|}{ Usia Anggota Rumah tangga } \\
\hline Usia dibawah 15 Tahun $($ ya = 1) & 0.000 & 0.016 \\
\hline Usia 15 sampai 64 Tahun $(y a=1)$ & 0.890 & 0.313 \\
\hline Usia di atas 64 Tahun $(\mathrm{ya}=1)$ & 0.110 & 0.313 \\
\hline Status Kepemilikan Rumah ( sewa = 1) & 0.031 & 0.174 \\
\hline Rumah tangga memiliki Televisi $(\mathrm{ya}=1)$ & 0.657 & 0.475 \\
\hline Rumah tangga Menggunakan Listrik $(\mathrm{ya}=1)$ & 0.926 & 0.261 \\
\hline Status Kepemilikan Toilet $($ sendiri $=1)$ & 0.667 & 0.471 \\
\hline Sumber Mata Air Utama Rumah tangga $($ sumur $=1)$ & 0.595 & 0.491 \\
\hline Bahan Bakar Rumah tangga Memasak (kayu bakar $=1$ ) & 0.448 & 0.497 \\
\hline Luas Lantai Rumah (m2) & 4.163 & 0.666 \\
\hline Pendapatan rumah tangga $(\ln )$ & 14.748 & 3.738 \\
\hline Jenis Dinding Rumah $($ tembok $=1)$ & 0.663 & 0.473 \\
\hline Jenis Dinding Rumah $(\mathrm{kayu}=1)$ & 0.236 & 0.425 \\
\hline Jenis Dinding Rumah $($ bambu $=1)$ & 0.095 & 0.294 \\
\hline Jenis Lantai Rumah Keramik $(y a=1)$ & 0.216 & 0.411 \\
\hline Jenis Lantai Rumah Ubin $($ ya $=1)$ & 0.200 & 0.400 \\
\hline Jenis Lantai Rumah Semen $($ ya $=1)$ & 0.331 & 0.471 \\
\hline Jenis Lantai Rumah Kayu $($ ya = 1) & 0.125 & 0.331 \\
\hline Jenis Lantai Rumah Bambu $(\mathrm{ya}=1)$ & 0.008 & 0.088 \\
\hline Jarak Desa Ke Kantor Pos terdekat (km) & 5.354 & 9.571 \\
\hline Jarak Desa Ke Ibukota Kab/Kota (km) & 21.579 & 25.032 \\
\hline Jarak Desa Ke Fasilitas Telepon terdekat (km) & 3.237 & 9.251 \\
\hline Jarak Desa ke Stasiun terdekat $(\mathrm{km})$ & 5.050 & 9.867 \\
\hline Jarak Desa ke Pangkalan Roda $2(\mathrm{~km})$ & 2.065 & 5.597 \\
\hline
\end{tabular}

Harapan).

Statistik deskriptif pada Tabel 1 menunjukkan bahwa transfer tunai pemerintah dalam bentuk tidak bersyarat (bantuan langsung tunai) yang diterima oleh rumah tangga memiliki rata-rata lebih besar dibandingkan bantuan bersyarat (program keluarga harapan) selama periode tahun 2007 mencapai 15,2 persen, sedangkan rumah tangga yang menerima bantuan program keluarga harapan kurang dari 5 persen. Hal ini mengindikasikan bahwa rumah tangga yang menerima transfer tunai dari bantuan pemerintah lebih banyak didominasi oleh transfer tunai tidak bersyarat (BLT) dalam hal ini adalah Bantuan Tunai Langsung dibandingkan Program Keluarga Harapan. 
Pada umumnya, pendidikan kepala rumah tangga adalah lulusan sekolah dasar yang mencapai 52,5 persen dengan rata-rata memiliki jumlah anggota sebesar 4-5 orang, lebih banyak didominasi oleh laki-laki (81,3 persen) dengan berstatus menikah sebesar 81 persen dan sebagian besar sudah bekerja (87,1 persen). Selain itu, usia anggota rumah tangga lebih banyak didominasi oleh usia produktif (15-64 tahun) yang mencapai 89 persen. Status kepemilikan rumah yang disewa oleh rumah tangga cukup rendah yaitu 3,1 persen, namun rata-rata sudah memiliki televisi sendiri (65,7 persen), menggunakan listrik (92,6 persen) dan sebagian besar memiliki toilet sendiri $(66,7$ persen).

Sementara itu, sumber air utama untuk minum yang masih menggunakan sumur cukup tinggi (59,5 persen), bahan bahan bakar utama rumah tangga untuk memasak yang masih menggunakan kayu bakar masih tinggi (44,8 persen) dan masih kurang sehatnya rumah yang dihuni karena tidak sesuai dengan batas yang disebut rumah sehat. Artinya, semakin sempit rumah maka tingkat kesehatan anggota keluarga akan terganggu karena terbatasnya ruang pergerakan udara dalam rumah. Kategori rumah sehat menurut World Health Organization adalah rumah yang memiliki luas lantai minimal $10 \mathrm{~m} 2$ per kapita (BPS, 2010), sedangkan umumnya luas lantai yang dihuni rumah tangga adalah 4,163 meter persegi. Selain itu, jenis dinding dan lantai luar rumah umumnya adalah tembok (66,3 persen) dan semen (33,1 persen).

Karateristik desa diwakili oleh akses ke infrastruktur atau fasilitas yang ada di pedesaan antara lain adalah jarak ke kantor pos terdekat, jarak ke ibukota kab/kota, jarak ke fasilitas telepon terdekat, jarak ke stasiun terdekat, jarak ke pangkalan roda 2. Berdasarkan karateristik desa menunjukkan bahwa Jarak antara kantor kepala desa ke berbagai fasilitas dan sarana prasarana umumnya cukup jauh. Jarak yang paling jauh adalah ke pusat ibukota kabupaten atau kota yang mencapai $22 \mathrm{~km}$, sedangkan ke fasilitas pangkalan kendaraan roda dua yang terdekat rata-rata mencapai $2 \mathrm{~km}$.

\section{HASIL PEMBAHASAN}

\section{Determinan Modal Sosial di Indonesia}

Pada Tabel 2. menunjukkan bahwa koefisien pendidikan kepala rumah tangga jenjang
Sekolah Dasar sampai Universitas berpengaruh positif terhadap modal sosial, baik dalam kegiatan arisan, siskamling, koperasi, kegiatan kerja bakti, karang taruna, pembinaan kesejahteraan keluarga (PKK) dan pertemuan warga serta signifikan secara statistik pada tingkat 1 sampai 5 persen. Dengan demikian, dapat disimpulkan bahwa tingkat pendidikan kepala rumah tangga berperan penting terhadap keterlibatannya dalam berbagai kegiatan modal sosial. Hal ini sejalan dengan penelitian sebelumnya yang menyatakan bahwa sekolah lebih baik daripada keluarga dalam berkontribusi terhadap penyebaran modal sosial (Aghion et $a l, 2010)$. Selain itu, walaupun individu dengan pendidikan memiliki biaya investasi lebih tinggi dalam modal sosial, namun juga menerima tingkat keuntungan yang lebih tinggi dari modal sosial. Oleh karena itu, individu yang berpendidikan tinggi akan berinvestasi lebih banyak dalam modal sosial karena keuntungan bersih (net benefit) yang akan diperoleh lebih tinggi (Jordan, Anil \& Munasib, 2005).

Jumlah anggota rumah tangga berpengaruh negatif terhadap modal sosial, terutama dalam kegiatan arisan, sedangkan dalam kegiatan karang taruna memperlihatkan hasil yang sebaliknya. Hal ini mengindikasikan bahwa semakin besar jumlah anggota rumah tangga maka banyak anggota rumah tangga yang menyumbang pendapatannya sehingga keterlibatan dalam arisan semakin rendah. Oleh karena itu, dengan besarnya ukuran rumah tangga maka cenderung untuk berpartisipasi dalam berbagai kegiatan modal sosial yang tidak memiliki motif ekonomi, dalam hal ini adalah kegiatan karang taruna. Selain itu, semakin besar anggota rumah tangga dalam suatu rumahhtangga maka memiliki waktu yang relatif kecil dalam melakukan kegiatan arisan, namun sebaliknya dalam rangka membantu satu sama lain secara informal. Hasil temuan ini sejalan dengan studi sebelumnya bahwa jumlah anggota rumah tangga berpengaruh negatif dalam berbagai kegiatan yang sifatnya rapat, namun berperan penting dalam kegiatan yang bersifat saling membantu satu sama lain (Wolz, Fritzsch \& Reinsberg, 2005).

Kepala rumah tangga berjenis kelamin perempuan berpengaruh positif terhadap modal sosial, terutama dalam kegiatan arisan dan pembinaan kesejahteraan keluarga (PKK), sedangkan dalam kegiatan siskamling, kerja bakti, perbaikan kampung, karang taruna dan pertemuan 
warga memperlihatkan hasil yang sebaliknya. Gender adalah hal yang paling penting dalam menentukan tingkat partisipasi dalam kegiatan, terutama arisan dan peningkatan pemberdayaan wanita melalui kegiatan PKK. Hal ini dikarenakan rumah tangga yang dikepalai oleh perempuan lebih cenderung untuk membutuhkan layanan keuangan arisan dan jejaring sosial yang diciptakan oleh adanya program pemberdayaan perempuan untuk mempertahankan tingkat konsumsinya dan bersosialisasi. Hasil temuan ini sejalan dengan studi sebelumnya bahwa perempuan memiliki probabilitas yang tinggi menjadi anggota dalam kegiatan arisan (Anderson and Baland, 2002 ; Varadharajan, 2004).

Kepala rumah tangga menikah berpengaruh positif terhadap modal sosial, terutama dalam kegiatan arisan dan pembinaan kesejahteraan keluarga (PKK), sedangkan dalam kegiatan karang taruna memperlihatkan hasil yang sebaliknya. Hal ini mengindikasikan apabila individu sudah menikah, khususnya perempuan maka lebih cenderung untuk berpartisipasi dalam kegiatan arisan dikarenakan adanya motif keuntungan secara ekonomi. Seorang perempuan yang sudah menikah memiliki sumber daya sendiri lebih banyak untuk mempertahankan rumah tangga sehingga kemungkinan akan bergabung dengan arisan. Selain itu, besarnya berkontribusi terhadap kegiatan arisan karena memiliki kemampuan untuk memanfaatkan pendapatan suaminya sehingga dapat membantu pendapatan rumatahngga.

Selain itu, kepala rumah tangga yang sudah menikah cenderung tebih banyak terlibat dalam interaksi sosial, misalnya kegiatan PKK karena memiliki peranan yang cukup besar dalam meningkatan status sosial rumah tangga. Hasil temuan ini sejalan dengan studi di Kenya yang menunjukkan bahwa kepala rumah tangga yang sudah menikah cenderung berpartisipasi aktif dalam kegiatan modal sosial, terutama arisan (Anderson dan Baland, 2002).

Kepala rumah tangga yang tidak bekerja berpengaruhnegatifterhadapmodal sosial, terutama dalamkegiatan siskamling kerja bakti dan perbaikan kampung. Hal ini mengindikasikan bahwa kepala rumah tangga tidak bekerja atau menganggur umumnya terkait dengan peningkatan waktu luang yang tersedia (leisure time) dan penurunan pada pendapatan. Dalam hal ini, individu yang tidak bekerja umumnya menghabiskan waktunya untuk aktivitas lain dibandingkan berpatisipasi atau bersosialisasi di masyarakat, misalnya lebih banyak menghabiskan waktunya di rumah. Selain itu, kepala rumah tangga yang tidak bekerja maka pendapatannya akan rendah sehingga kemampuan untuk menyisihkan pendapatannya sangat kecil dengan berpartisipasi dalam kegiatan modal sosial, terutama keterlibatannya dalam kegiatan arisan. Hasil temuan ini sejalan dengan studi sebelumnya yang menyatakan bahwa pengangguran cenderung dapat mengurangi tingkat interaksi dan partisipasi sosial (Lars \& Suppa, 2014).

Anggota rumah tangga kelompok usia, baik usia produktif (15-64 tahun) maupun tidak produktif (di atas 64 tahun) berpengaruh positif terhadap modal sosial, terutama dalam kegiatan arisan, siskamling, koperasi, kerja bakti, perbaikan kampung dan pertemuan warga. Dalam hal ini, usia produktif lebih banyak terlibat dalam kegiatan modal sosial karena pada usia ini lebih produktif memberikan peluang dan potensi guna meningkatkan pendapatan. Pendapatan yang tinggi memungkinkan keluarga untuk dapat memenuhi kebutuhannya dan menyisihkan sebagian pendapatannya untuk melakukan kegiatan modal sosial, terutama arisan. Sementara itu, aktifnya keterlibatan dalam kegiatan siskamling, koperasi, kerja bakti, perbaikan kampung dan pertemuan warga adalah untuk bersosialisasi dengan warga.

Sementara itu, usia diatas 65 tahun sudah sangat berpengalaman dan banyak mengetahui tentang keadaan yang lalu, namun terkadang terkendala akibat keterbatasan fisik yang dimiliki untuk mengikuti kegiatan modal sosial sehingga keterlibatannya terhadap kegiatan modal sosial semakin berkuang. Hasil temuan ini ini sejalan dengan studi sebelumnya yang menunjukkan bahwa usia produktif cenderung dapat melakukan kerja yang produktif sehingga berhubungan positif dengan berbagai indikator modal sosial dari keterlibatan masyarakat (Van Ingen \& Van Eijck, 2009).

Status kepemilikan rumah adalah sewa berpengaruh negatif terhadap modal sosial, terutama pembinaan kesejahteraan keluarga (PKK). Hal ini mengindikasikan bahwa rumah tangga yang memiliki status kepemilikan rumahnya sewa cenderung untuk tidak terlibat dalam pembinaan kesejahteraan keluarga (PKK). Dalam hal ini, rumah yang disewa umumnya bersifat jangka pendek dan kecenderungan tidak tinggal cukup 
lama dan berpindah-pindah. Dengan demikian, insentif rumah tangga untuk terlibat dalam interaksi sosial, khususnya pembinaan kesejahteraan rumah tangga sangat kecil.

Sementara itu, kepemilikan televisi berpengaruh positif terhadap modal sosial, terutama dalam kegiatan arisan, perbaikan kampung, PKK dan pertemuan warga. Temuan ini mengindikasikan bahwa kepemilikan televisi berperan penting dalam meningkatkan keterlibatan rumah tangga dalam kegiatan modal sosial karena dapat memberikan informasi bermanfaat dan menurunkan biaya transaaksi pada saat bertemua atau terlibat dengan masyarakat lainya yang merupakan bagian dari efek positif yang dimiliki televisi terhadap kegiatan sosial. Hal ini sejalan dengan studi yang dilakukan sebelumnya bahwa televisi dan media informasi memiliki pengaruh positif terhadap modal sosial (Hooghe \& Oser, 2015).

Hasil temuan yang sama menunjukkan bahwa rumah tangga yang sudah memiliki jamban atau toilet sendiri berpengaruh positif terhadap kegiatan koperasi, perbaikan kampung dan pembinaan kesejahteraan keluarga (PKK). Hasil ini sejalan dengan studi sebelumnya, dimana apabila suatu rumah tangga membangun toilet sendiri dan memperoleh akses sanisasi lebih mudah dan berhenti buang air besar maka penduduk desa lainnya mendapat keuntungan. Apabila masyarakat dengan tingkat modal sosial yang lebih tinggi dapat menginternalisasi manfaat sosial ini maka cenderung masyarakat lebih tertarik dan bersedia bekerja sama untuk memperbaiki sanitasi karena dapat memperbaiki tingkat kesehatan masyarakat, terutama di komunitas pedesaan (Cameron \& Olivia, 2010). Hal yang sama pada sumber air utama untuk minum yang masih menggunakan sumur berpengaruh positif terhadap modal sosial, terutama kegiatan karang taruna dan pertemuan warga, sedangkan dalam kegiatan arisan berpengaruh negatif.

Luas lantai yang dihuni rumah tangga berpengaruh positif terhadap modal sosial, terutama dalam kegiatan arisan. Hal ini mengindikasikan bahwa semakin luas lantai rumah yang dihuni oleh rumah tangga maka keterlibatan dalam kegiatan arisan semakin besar. Semakin luas lantai rumah yang dihuni secara tidak langsung mencerminkan tingkat kesejahteraan rumah tangga yang lebih tinggi sehinggamemiliki potensiuntukmenyisihkan sebagian pendapatannya untuk tabungan (saving) melalui kegiatan arisan. Sementara itu, bahan bahan bakar utama rumah tangga untuk memasak yang masih menggunakan kayu bakar berpengaruh negatif terhadap kegiatan arisan.

Pendapatan rumah tangga berpengaruh positif terhadap modal sosial, terutama dalam kegiatan arisan, kegiatan kerja bakti dan karang taruna. Dalam hal ini, individu yang memiliki pendapatan tinggi lebih memungkinkan memikirkan mekanisme perlindungan (insurance mechanism) ketika terjadi guncangan pendapatan, misalnya terjadi peningkatan harga yang disebabkan oleh terjadinya kenaikan BBM dengan menabung sebagian pendapatannya melalui kegiatan arisan. Selain itu, untuk mendapatkan pengembalian modal sosial yang lebih tinggi jika melakukan investasi kolektif di komunitas, terutama pada kegiatan arisan. Hasil temuan ini sejalan dengan penelitian sebelumnya yang membahas hubungan antara investasi modal sosial individu dan masyarakat, dimana semakin tinggi investasi yang dilakukan dalam kegiatan modal sosial maka tingkat pengembaliannya yang akan diperoleh lebih tinggi (Glaeser, 2001).

Jenis dinding dan lantai luar rumah tembok, semen dan kayu berpengaruh positif terhadap kegiatan koperasi. Selain itu, jenis lantai luar rumah yan dihuni rumah tangga, terutama yang terbuat dari semen berpengaruh positif terhadap modal sosial, terutama dalam kegiatan arisan dan karang taruna. Hal ini mengindikasikan bahwa rumah tangga yang memiliki jenis dinding dan lantai luar rumah tembok, semen dan lantai rumah terluas terbuat dari semen (umumnya merupakan rumah tangga yang mampu secara ekonomi) lebih berperan aktif dalam kegiatan modal sosial.

Berdasarkan karateristik desa menunjukkan bahwa akses dari desa ke infrastruktur atau fasilitas yang ada di pedesaan, terutama ke kantor pos terdekat berpengaruh negatif terhadap modal sosial, terutama terhadap kegiatan perbaikan kampung dan pertemuan warga, sedangkan pada kegiatan karang taruna berpengaruh positif. Hal ini mengindikasikan bahwa semakin jauh jarak akses dari desa ke fasilitas kantor pos terdekat maka keterlibatan atau partisipasi rumah tangga terhadap berbagai kegiatan kemasyarakatan akan rendah. Kondisi ini menunjukkan bahwa semakin jauh akses ke pembangunan infrastruktur desa yang menjadi katalisator modal sosial akan semakin 
rendah, terutama terhadap berbagai kegiatan modal sosial yang berkaitan dengan sosialisasi, misalnya pertemuan warga.

Hal yang sama mengenai akses ke ibukota kabupaten/kotaberpengaruhnegatifterhadapmodal sosial, khususnya partisipasi terhadap kegiatan siskamling, koperasi dan karang taruna. Akses ke terminal atau stasiun terdekat berpengaruh negatif terhadap modal sosial, khususnya berpartisipasi terhadap kegiatan koperasi dan berpengaruh negatif terhadap kegiatan PKK. Selanjutnya, akses ke fasilitas telepon terdekat berpengaruh positif terhadap modal sosial, khususnya berpartisipasi terhadap kegiatan koperasi dan berpengaruh negatif terhadap kegiatan PKK. Situasi ini menggambarkan bahwa semakin jauh akses ke fasilitas telepon terdekat maka keterlibatan rumah tangga untuk berperan aktif dalam kegiatan sosialisasi melalui PKK semakin berkurang, sedangkan mengikuti keanggotaan koperasi di desa semakin bertambah. Terakhir, koefisien akses ke pangkalan kendaraan roda 2 berpengaruh positif terhadap modal sosial, terutama peran aktif pada perbaikan kampung dan karang taruna.

\section{Dampak Bantuan Langsung Tunai Terhadap Modal Sosial}

(BLT)

Tabel 3 menunjukkan hasil estimasi OLS dan fixed effect pada tingkat desa untuk mengetahui dampak program bantuan langsung tunai terhadap modal sosial di Indonesia tanpa memperhitungkan variabel-variabel lainnya. Berdasarkan hasil estimasiOLSmenunjukkanbahwa dampak program bantuan tunai langsung yang diterima oleh rumah tangga berpengaruh positif terhadap modal sosial, namun tidak signifikan secara statistik. Sementara itu, melalui teknik estimasi fixed effect tingkat desa menunjukkan bahwa dampak program bantuan langsung tunai berpengaruh positif terhadap modal sosial sebesar 0,056 serta signifikan secara statistik pada tingkat 10 persen, khususnya pada partisipasi rumah tangga dalam kegiatan arisan. Artinya, secara rata-rata jika bantuan tunai langsung yang diterima oleh rumah tangga naik 1 sebesar persen maka partisipasi rumah tangga dalam kegiatan arisan akan naik 5,6 persen dengan asumsi cateris paribus.

Temuan yang sama dalam Tabel 4 bahwa dampak bantuan tunai langsung yang diterima oleh rumah tangga dengan memperhitungkan variabel-variabel kontrol lainnya menunjukkan hasil yang konsisten dengan estimasi sebelumnya, dimana berdampak positif terhadap modal sosial dalam bentuk partisipasi rumah tangga kegiatan arisan di Indonesia sebesar 0,054 dan signifikan secara statistik pada tingkat 10 persen. Hasil estimasi menunjukkan bahwa pendekatan dengan fixed effect pada tingkat desa secara jelas menghasilkan estimasi yang berbeda dengan OLS. Hal ini menunjukkan bahwa dalam kegiatan partisipasi masyarakat, terutama arisan lebih banyak dipengaruhi oleh faktor yang tidak teramati (unobserved heterogeneity). Hasil estimasi menunjukkan bahwa bantuan langsung tunai berpengaruh positif terhadap partisipasi kegiatan arisan. Hal ini mengindikasikan bahwa rumah tangga yang menerima bantuan pemerintah melalui bantuan tunai langsung lebih aktif dalam kegiatan arisan dan secara tidak langsung berperan dalam penguatan modal sosial. Salah satu motivasi rumah tangga mengikuti partisipasi kegiatan arisan antara lain adalah untuk memiliki akses kredit dan kemampuan untuk mempertahankan daya beli atau melakukan consumption smoothing pada saat terjadi kenaikan harga bahan bakar minyak (BBM) di Indonesia. Dengan demikian, modal sosial dalam bentuk arisan bisa dikatakan sebagai bentuk transfer uang antar individu dalam rangka memperkuat ikatan sosial antar anggota masyarakat. Selain itu, arisan merupakan salah satu lembaga keuangan non formal yang umumnya dimanfaatkan oleh rumah tangga, baik di perkotaan maupun pedesaan.

Hasil temuan ini sejalan dengan temuan sebelumya yang menunjukkan bahwa rumah tangga yang berpartisipasi aktif dalam kegiatan modal sosial, terutama yang memiliki peran dalam keuangan (misalnya, rotating credit dan savings associations) memiliki beberapa keuntungan jangka panjang, seperti akses kredit dan kemampuan yang lebih baik untuk mengatasi fluktuasi pendapatan dengan meminjam atau mengumpulkan aset (Grootaert,1999).

\section{Dampak Program Keluarga Harapan (PKH) Terhadap Modal Sosial}

Hasil estimasi fixed effect pada tingkat desa dalam Tabel 5. menunjukkan bahwa program PKH memiliki dampak negatif terhadap modal sosial, namun tidak menunjukkan tingkat signifikansi secara statistik. Demikian halnya, pada Tabel 6. dengan memperhitungkan berbagai karateristik rumah tangga dan desa memperlihatkan hasil yang konsisten dengan estimasi sebelumnya. 
Tabel 2. Determinan Modal Sosial

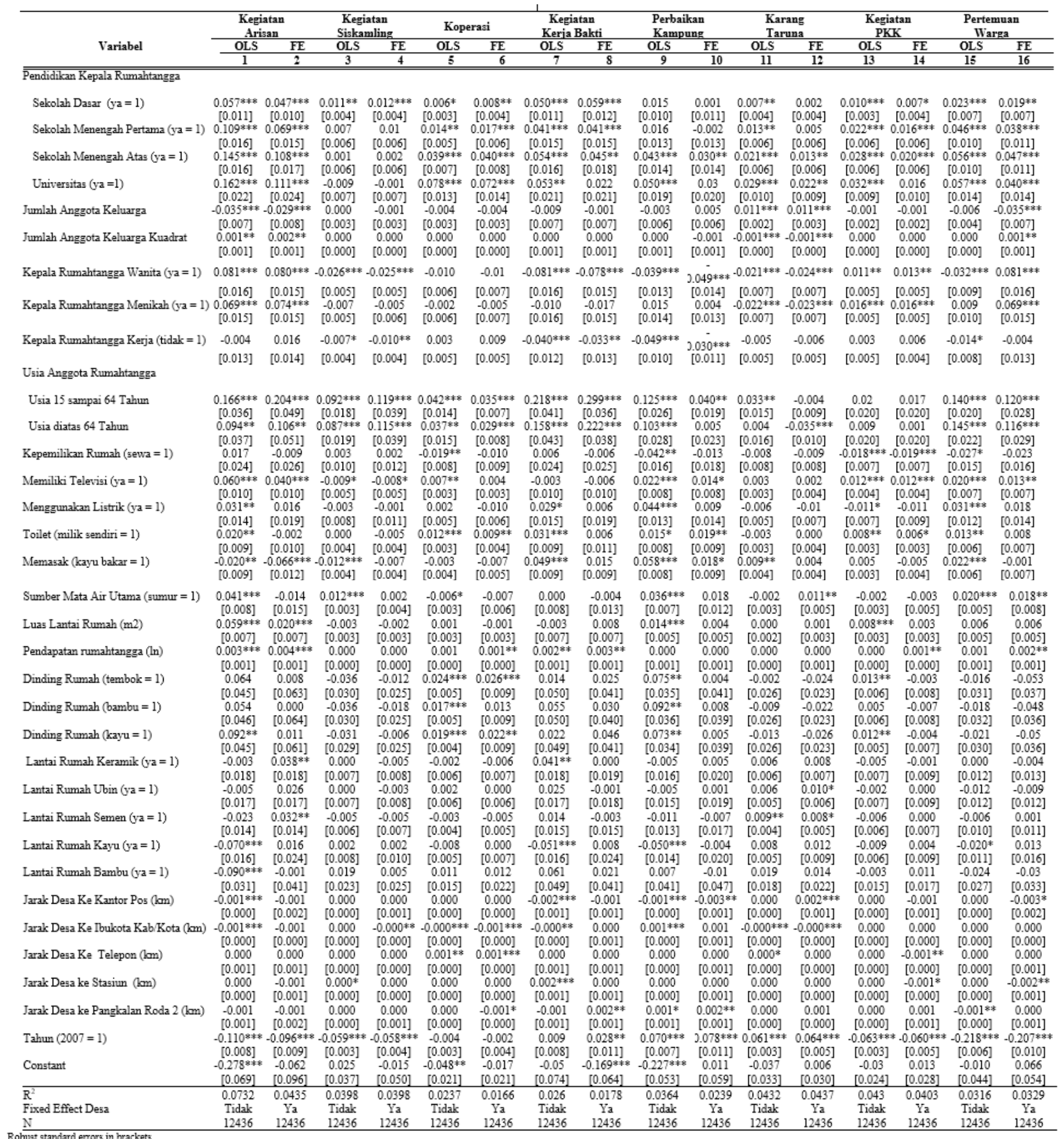

Robuat standard errors in brackets
$0<00.1, * 4 \mathrm{p}<0.05, \leftrightarrow \rightarrow \infty$ p $<0.01$

Tabel 3. Dampak Bantuan Langsung Tunai (BLT)

Terhadap Modal Sosial

\begin{tabular}{|c|c|c|c|c|c|c|c|c|c|c|c|c|c|c|c|c|}
\hline \multirow{3}{*}{ Variabel } & \multicolumn{2}{|c|}{$\begin{array}{c}\begin{array}{c}\text { Kegiatan } \\
\text { Arisan }\end{array} \\
\end{array}$} & \multicolumn{2}{|c|}{$\begin{array}{c}\text { Kegiatan } \\
\text { Siskamling } \\
\end{array}$} & \multicolumn{2}{|c|}{ Koperasi } & \multicolumn{2}{|c|}{$\begin{array}{c}\text { Kegiatan } \\
\text { Kerja Bakti } \\
\end{array}$} & \multicolumn{2}{|c|}{$\begin{array}{c}\text { Perbaikan } \\
\text { Kampung } \\
\end{array}$} & \multicolumn{2}{|c|}{$\begin{array}{c}\text { Karang } \\
\text { Taruna }\end{array}$} & \multicolumn{2}{|c|}{$\begin{array}{c}\text { Kegiatan } \\
\text { PKK }\end{array}$} & \multicolumn{2}{|c|}{$\begin{array}{c}\text { Pertemuan } \\
\text { Warga }\end{array}$} \\
\hline & OLS & $\mathrm{FE}$ & OLS & $\mathrm{FE}$ & OLS & FE & OLS & $\mathrm{FE}$ & OLS & $\mathrm{FE}$ & OLS & FE & OLS & $\mathrm{FE}$ & OLS & $\mathrm{FE}$ \\
\hline & (1) & (2) & (3) & (4) & (5) & (6) & $(7)$ & $(8)$ & (9) & (10) & (11) & (12) & (13) & (14) & (15) & (16) \\
\hline Tahun 2007 x BLT & $\begin{array}{c}0.056 \\
{[0.034]}\end{array}$ & $\begin{array}{l}0.056^{*} \\
{[0.028]}\end{array}$ & $\begin{array}{l}-0.008 \\
{[0.012]}\end{array}$ & $\begin{array}{l}-0.008 \\
{[0.016]}\end{array}$ & $\begin{array}{l}-0.005 \\
{[0.019]}\end{array}$ & $\begin{array}{l}-0.005 \\
{[0.028]}\end{array}$ & $\begin{array}{l}-0.035 \\
{[0.034]}\end{array}$ & $\begin{array}{l}-0.035 \\
{[0.034]}\end{array}$ & $\begin{array}{c}0.015 \\
{[0.023]}\end{array}$ & $\begin{array}{c}0.015 \\
{[0.030]}\end{array}$ & $\begin{array}{l}-0.017 \\
{[0.014]}\end{array}$ & $\begin{array}{l}-0.017 \\
{[0.016]}\end{array}$ & $\begin{array}{c}0.012 \\
{[0.014]}\end{array}$ & $\begin{array}{c}0.012 \\
{[0.015]}\end{array}$ & $\begin{array}{c}0.009 \\
{[0.022]}\end{array}$ & $\begin{array}{c}0.009 \\
{[0.035]}\end{array}$ \\
\hline Constant & $\begin{array}{c}0.366^{* * *} \\
{[0.025]}\end{array}$ & $\begin{array}{c}0.316^{* * *} \\
{[0.004]}\end{array}$ & $\begin{array}{c}0.055^{* * *} \\
{[0.012]}\end{array}$ & $\begin{array}{c}0.062^{* * *} \\
{[0.002]}\end{array}$ & $\begin{array}{c}0.068^{* * *} \\
{[0.013]}\end{array}$ & $\begin{array}{c}0.031^{* * *} \\
{[0.002]}\end{array}$ & $\begin{array}{c}0.238^{* * *} \\
{[0.022]}\end{array}$ & $\begin{array}{c}0.237 * * * \\
{[0.005]}\end{array}$ & $\begin{array}{c}0.071^{* * *} \\
{[0.013]}\end{array}$ & $\begin{array}{c}0.129^{* * *} \\
{[0.005]}\end{array}$ & $\begin{array}{c}0.000^{* * * *} \\
{[0.000]}\end{array}$ & $\begin{array}{c}0.000 \\
{[0.002]}\end{array}$ & $\begin{array}{c}0.068^{* * *} \\
{[0.013]}\end{array}$ & $\begin{array}{c}0.057^{* * *} \\
{[0.002]}\end{array}$ & $\begin{array}{c}0.216^{* * *} \\
{[0.022]}\end{array}$ & $\begin{array}{c}0.207^{* * *} \\
{[0.005]}\end{array}$ \\
\hline $\mathrm{R}^{2}$ & 0.0087 & 0.0104 & 0.0321 & 0.0337 & 0.0034 & 0.000 & 0.001 & 0.001 & 0.0126 & 0.0119 & 0.0314 & 0.0325 & 0.0293 & 0.0313 & 0.0155 & 0.0228 \\
\hline $\begin{array}{l}\text { Fixed Effect Desa } \\
\text { Variabel Kontrol }\end{array}$ & $\begin{array}{l}\text { Tidak } \\
\text { Tidak }\end{array}$ & $\begin{array}{l}\text { Ya } \\
\text { Tidak }\end{array}$ & $\begin{array}{l}\text { Tidak } \\
\text { Tidak }\end{array}$ & $\begin{array}{c}\text { Ya } \\
\text { Tidak }\end{array}$ & $\begin{array}{l}\text { Tidak } \\
\text { Tidak }\end{array}$ & $\begin{array}{l}\text { Ya } \\
\text { Tidak }\end{array}$ & $\begin{array}{l}\text { Tidak } \\
\text { Tidak }\end{array}$ & $\begin{array}{l}\text { Ya } \\
\text { Tidak }\end{array}$ & $\begin{array}{l}\text { Tidak } \\
\text { Tidak }\end{array}$ & $\begin{array}{c}\text { Ya } \\
\text { Tidak }\end{array}$ & $\begin{array}{l}\text { Tidak } \\
\text { Tidak }\end{array}$ & $\begin{array}{l}\text { Ya } \\
\text { Tidak }\end{array}$ & $\begin{array}{l}\text { Tidak } \\
\text { Tidak }\end{array}$ & $\begin{array}{c}\text { Ya } \\
\text { Tidak }\end{array}$ & $\begin{array}{l}\text { Tidak } \\
\text { Tidak }\end{array}$ & $\begin{array}{c}\text { Ya } \\
\text { Tidak }\end{array}$ \\
\hline $\mathrm{N}$ & 12436 & 12436 & 12436 & 12436 & 12436 & 12436 & 12436 & 12436 & 12436 & 12436 & 12436 & 12436 & 12436 & 12436 & 12436 & 12436 \\
\hline
\end{tabular}


Tabel 4. Dampak Bantuan Langsung Tunai (BLT) Terhadap Modal Sosial

\begin{tabular}{|c|c|c|c|c|c|c|c|c|c|c|c|c|c|c|c|c|}
\hline \multirow{3}{*}{ Variabel } & \multicolumn{2}{|c|}{$\begin{array}{c}\begin{array}{c}\text { Kegiatan } \\
\text { Arisan }\end{array} \\
\end{array}$} & \multicolumn{2}{|c|}{$\begin{array}{c}\begin{array}{c}\text { Kegiatan } \\
\text { Siskamling }\end{array} \\
\end{array}$} & \multicolumn{2}{|c|}{ Koperasi } & \multicolumn{2}{|c|}{$\begin{array}{c}\text { Kegiatan } \\
\text { Kerja Bakti } \\
\end{array}$} & \multicolumn{2}{|c|}{$\begin{array}{c}\text { Perbaikan } \\
\text { Kampung } \\
\end{array}$} & \multicolumn{2}{|c|}{$\begin{array}{l}\text { Karang } \\
\text { Taruna }\end{array}$} & \multicolumn{2}{|c|}{$\begin{array}{c}\text { Kegiatan } \\
\text { PKK }\end{array}$} & \multicolumn{2}{|c|}{$\begin{array}{c}\text { Pertemuan } \\
\text { Warga }\end{array}$} \\
\hline & OLS & $\mathrm{FE}$ & OLS & $\mathrm{FE}$ & OLS & $\mathrm{FE}$ & OLS & FE & OLS & $\mathrm{FE}$ & OLS & $\mathrm{FE}$ & OLS & $\mathrm{FE}$ & OLS & $\mathrm{FE}$ \\
\hline & (1) & (2) & (3) & (4) & (5) & $(6)$ & $(7)$ & $(8)$ & (9) & (10) & (11) & (12) & (13) & (14) & $(15)$ & (16) \\
\hline Tahun 2007 x BLT & $\begin{array}{c}0.056 \\
{[0.034]}\end{array}$ & $\begin{array}{l}0.056^{*} \\
{[0.028]}\end{array}$ & $\begin{array}{l}-0.008 \\
{[0.012]}\end{array}$ & $\begin{array}{l}-0.008 \\
{[0.016]}\end{array}$ & $\begin{array}{l}-0.005 \\
{[0.019]}\end{array}$ & $\begin{array}{l}-0.005 \\
{[0.028]}\end{array}$ & $\begin{array}{l}-0.035 \\
{[0.034]}\end{array}$ & $\begin{array}{l}-0.035 \\
{[0.034]}\end{array}$ & $\begin{array}{c}0.015 \\
{[0.023]}\end{array}$ & $\begin{array}{c}0.015 \\
{[0.030]}\end{array}$ & $\begin{array}{l}-0.017 \\
{[0.014]}\end{array}$ & $\begin{array}{l}-0.017 \\
{[0.016]}\end{array}$ & $\begin{array}{c}0.012 \\
{[0.014]}\end{array}$ & $\begin{array}{c}0.012 \\
{[0.015]}\end{array}$ & $\begin{array}{c}0.009 \\
{[0.022]}\end{array}$ & $\begin{array}{c}0.009 \\
{[0.035]}\end{array}$ \\
\hline Constant & $\begin{array}{c}0.366^{* * *} \\
{[0.025]}\end{array}$ & $\begin{array}{c}0.316^{* * *} \\
{[0.004]}\end{array}$ & $\begin{array}{c}0.055^{* * *} \\
{[0.012]} \\
\end{array}$ & $\begin{array}{c}0.062^{* * *} \\
{[0.002]}\end{array}$ & $\begin{array}{c}0.068^{* * *} \\
{[0.013]}\end{array}$ & $\begin{array}{c}0.031^{* * *} \\
{[0.002]}\end{array}$ & $\begin{array}{c}0.238^{* * *} \\
{[0.022]} \\
\end{array}$ & $\begin{array}{c}0.237 * * * \\
{[0.005]}\end{array}$ & $\begin{array}{c}0.071^{* * *} \\
{[0.013]}\end{array}$ & $\begin{array}{c}0.129^{* * *} \\
{[0.005]}\end{array}$ & $\begin{array}{c}0.000^{* * *} \\
{[0.000]}\end{array}$ & $\begin{array}{c}0.000 \\
{[0.002]}\end{array}$ & $\begin{array}{c}0.068^{* * *} \\
{[0.013]}\end{array}$ & $\begin{array}{c}0.057^{* * * *} \\
{[0.002]}\end{array}$ & $\begin{array}{c}0.216^{* * *} \\
{[0.022]} \\
\end{array}$ & $\begin{array}{c}0.207^{* * * *} \\
{[0.005]}\end{array}$ \\
\hline $\mathrm{R}^{2}$ & 0.0087 & 0.0104 & 0.0321 & 0.0337 & 0.0034 & 0.000 & 0.001 & 0.001 & 0.0126 & 0.0119 & 0.0314 & 0.0325 & 0.0293 & 0.0313 & 0.0155 & 0.0228 \\
\hline $\begin{array}{l}\text { Fixed Effect Desa } \\
\text { Variabel Kontrol } \\
\mathrm{N}\end{array}$ & $\begin{array}{l}\text { Tidak } \\
\text { Tidak } \\
12436\end{array}$ & $\begin{array}{l}\text { Ya } \\
\text { Tidak } \\
12436\end{array}$ & $\begin{array}{l}\text { Tidak } \\
\text { Tidak } \\
12436\end{array}$ & $\begin{array}{l}\text { Ya } \\
\text { Tidak } \\
12436\end{array}$ & $\begin{array}{l}\text { Tidak } \\
\text { Tidak } \\
12436\end{array}$ & $\begin{array}{l}\text { Ya } \\
\text { Tidak } \\
12436\end{array}$ & $\begin{array}{l}\text { Tidak } \\
\text { Tidak } \\
12436\end{array}$ & $\begin{array}{l}\text { Ya } \\
\text { Tidak } \\
12436\end{array}$ & $\begin{array}{l}\text { Tidak } \\
\text { Tidak } \\
12436\end{array}$ & $\begin{array}{c}\text { Ya } \\
\text { Tidak } \\
12436\end{array}$ & $\begin{array}{l}\text { Tidak } \\
\text { Tidak } \\
12436\end{array}$ & $\begin{array}{l}\text { Ya } \\
\text { Tidak } \\
12436\end{array}$ & $\begin{array}{l}\text { Tidak } \\
\text { Tidak } \\
12436\end{array}$ & $\begin{array}{c}\text { Ya } \\
\text { Tidak } \\
12436\end{array}$ & $\begin{array}{l}\text { Tidak } \\
\text { Tidak } \\
12436\end{array}$ & $\begin{array}{c}\text { Ya } \\
\text { Tidak } \\
12436\end{array}$ \\
\hline
\end{tabular}

Tabel 5. Dampak Program Keluarga Harapan (PKH)

Terhadap Modal Sosial

\begin{tabular}{|c|c|c|c|c|c|c|c|c|c|c|c|c|c|c|c|c|}
\hline \multirow{3}{*}{ Variabel } & \multicolumn{2}{|c|}{$\begin{array}{c}\begin{array}{c}\text { Kegiatan } \\
\text { Arisan }\end{array} \\
\end{array}$} & \multicolumn{2}{|c|}{$\begin{array}{c}\text { Kegiatan } \\
\text { Siskamling } \\
\end{array}$} & \multicolumn{2}{|c|}{ Koperasi } & \multicolumn{2}{|c|}{$\begin{array}{c}\text { Kegiatan } \\
\text { Kerja Bakti }\end{array}$} & \multicolumn{2}{|c|}{$\begin{array}{l}\text { Perbaikan } \\
\text { Kampung } \\
\end{array}$} & \multicolumn{2}{|c|}{$\begin{array}{c}\text { Karang } \\
\text { Taruna }\end{array}$} & \multicolumn{2}{|c|}{$\begin{array}{c}\text { Kegiatan } \\
\text { PKK } \\
\end{array}$} & \multicolumn{2}{|c|}{$\begin{array}{c}\text { Pertemuan } \\
\text { Warga }\end{array}$} \\
\hline & OLS & $\mathrm{FE}$ & OLS & $\mathrm{FE}$ & OLS & $\mathrm{FE}$ & OLS & FE & OLS & $\mathrm{FE}$ & OLS & $\mathrm{FE}$ & OLS & $\mathrm{FE}$ & OLS & $\mathrm{FE}$ \\
\hline & (1) & (2) & (3) & (4) & $(5)$ & (6) & $(7)$ & (8) & $(9)$ & (10) & (11) & (12) & (13) & (14) & (15) & (16) \\
\hline Tahun 2007 x PKH & $\begin{array}{l}-0.057 \\
{[0.042]}\end{array}$ & $\begin{array}{l}-0.057 \\
{[0.045]}\end{array}$ & $\begin{array}{c}-0.053^{* *} \\
{[0.022]}\end{array}$ & $\begin{array}{l}-0.053 \\
{[0.033]}\end{array}$ & $\begin{array}{l}-0.015 \\
{[0.016]}\end{array}$ & $\begin{array}{l}-0.015 \\
{[0.012]}\end{array}$ & $\begin{array}{l}-0.016 \\
{[0.042]}\end{array}$ & $\begin{array}{l}-0.016 \\
{[0.057]}\end{array}$ & $\begin{array}{l}-0.038 \\
{[0.038]}\end{array}$ & $\begin{array}{l}-0.038 \\
{[0.028]}\end{array}$ & $\begin{array}{l}-0.011 \\
{[0.015]}\end{array}$ & $\begin{array}{c}-0.011 \\
{[0.021]}\end{array}$ & $\begin{array}{l}-0.021 \\
{[0.018]}\end{array}$ & $\begin{array}{l}-0.021 \\
{[0.040]}\end{array}$ & $\begin{array}{c}0.012 \\
{[0.027]}\end{array}$ & $\begin{array}{c}0.012 \\
{[0.051]}\end{array}$ \\
\hline Constant & $\begin{array}{c}0.316^{* * *} \\
{[0.006]}\end{array}$ & $\begin{array}{c}0.316^{* * *} \\
{[0.004]}\end{array}$ & $\begin{array}{c}0.060^{* * *} \\
{[0.003]}\end{array}$ & $\begin{array}{c}0.062^{* * *} \\
{[0.002]}\end{array}$ & $\begin{array}{c}0.030^{* * *} \\
{[0.002]}\end{array}$ & $\begin{array}{c}0.031^{* * *} \\
{[0.002]}\end{array}$ & $\begin{array}{c}0.236^{* * *} \\
{[0.005]}\end{array}$ & $\begin{array}{c}0.237^{* * *} \\
{[0.005]}\end{array}$ & $\begin{array}{c}0.128^{* * *} \\
{[0.004]}\end{array}$ & $\begin{array}{c}0.129 * * * \\
{[0.005]}\end{array}$ & $\begin{array}{r}0.000 \\
{[0.000]}\end{array}$ & $\begin{array}{c}0.000 \\
{[0.002]}\end{array}$ & $\begin{array}{c}0.056^{* * *} \\
{[0.003]}\end{array}$ & $\begin{array}{c}0.057^{* * *} \\
{[0.002]}\end{array}$ & $\begin{array}{c}0.207 * * * \\
{[0.005]}\end{array}$ & $\begin{array}{c}0.207^{* * *} \\
{[0.005]}\end{array}$ \\
\hline $\mathrm{R}^{2}$ & 0.0085 & 0.0103 & 0.0337 & 0.0345 & 0.0001 & 0.0001 & 0.0008 & 0.0009 & 0.0109 & 0.012 & 0.0312 & 0.0324 & 0.0294 & 0.0314 & 0.0155 & 0.0228 \\
\hline Fixed Effect Desa & Tidak & $\mathrm{Ya}$ & Tidak & $\mathrm{Ya}$ & Tidak & Ya & Tidak & Ya & Tidak & Ya & Tidak & $\mathrm{Ya}$ & Tidak & $\mathrm{Ya}$ & Tidak & $\mathrm{Ya}$ \\
\hline Variabel Kontrol & Tidak & Tidak & Tidak & Tidak & Tidak & Tidak & Tidak & Tidak & Tidak & Tidak & Tidak & Tidak & Tidak & Tidak & Tidak & Tidak \\
\hline $\mathrm{N}$ & 12436 & 12436 & 12436 & 12436 & 12436 & 12436 & 12436 & 12436 & 12436 & 12436 & 12436 & 12436 & 12436 & 12436 & 12436 & 12436 \\
\hline
\end{tabular}

Tabel 6. Dampak Program Keluarga Harapan (PKH)

Terhadap Modal Sosial

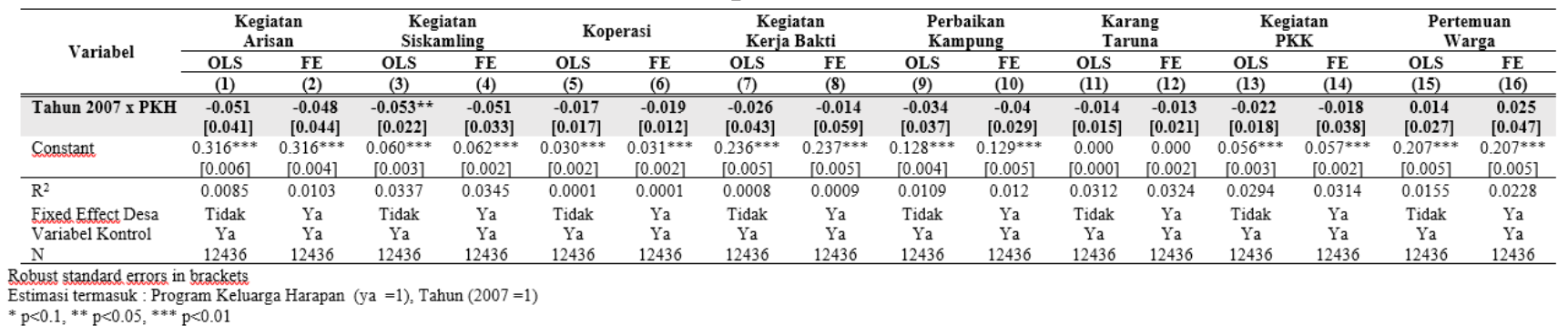

Hasil temuan ini mengindikasikan bahwa rumah tangga yang menerima bantuan Program Keluarga Harapan cenderung tidak aktif atau terlibat dalam kegiatan modal sosial. Hal tersebut antara lain dapat disebabkan karena : (1) buruknya atau tidak tersedianya infrastruktur dasar seperti jalan, jembatan, listrik, dan air bersih, khususnya di daerah terpencil. Dengan demikian, upaya untuk penguatan jaringan sosial relatif rendah; (2) kurangnya dukungan mayarakat terhadap PKH; (3) lemahnya peran pendamping dalam membimbing dan mengawasi kepatuhan penerima program agar dapat bersosialisasi dengan rumah tangga lainnya; (4) adanya potensi kecemburuan dan konflik dari non-penerima bantuan $\mathrm{PKH}$, terutama di daerah desa/kelurahan dengan jumlah penerima PKH relatif sedikit sehingga dapat berpotensi menghancurkan ikatan sosial dalam suatu masyarakat.

Program Keluarga Harapan (PKH) adalah program pemberian uang tunai kepada Rumah tangga Sangat Miskin (RTSM) dengan persyaratan dan ketentuan yang telah ditetapkan dengan melaksanakan kewajibannya atau program conditional cash transfers (CCT). Persyaratan tersebut berupa kehadiran di fasilitas pendidikan (misalnya bagi anak usia sekolah), ataupun kehadiran di fasilitas kesehatan (misalnya bagi anak balita, atau bagi ibu hamil. Dengan demikian, dampak program tersebut terhadap modal sosial seperti kegiatan arisan, siskamling, koperasi, kerja bakti, perbaikan kampung, karang taruna dan Pembinaan Kesejahteraan Keluarga (PKK) tidak berpengaruh signifikan secara statistik.

Hasil temuan ini sejalan dengan studi sebelumnya yang menunjukkan bahwa banyak peserta PKH yang tidak aktif dalam mengikuti beberapa kegiatan yang ada di masyarakat karena kesadaran dalam mengikuti kegiatan tersebut masih rendah (Aminudin, 2014). Selain itu, program Keluarga Harapan (PKH) tidak ditujukan untuk mempertahankan daya beli atau melakukan consumption smoothing pada saat terjadi kenaikan harga, termasuk gejolak akibat kenaikan bahan 
bakar minyak (BBM).

\section{KESIMPULAN}

Ada beberapa temuan dari studi ini yang dapat disimpulkan. Pertama. rumah tangga penerima bantuan tidak bersyarat (unconditional cash transfer) yaitu program pemerintah BLT lebih aktif terlibat dalam modal sosial, terutama dalam kegiatan arisan. Hasil temuan ini mengindikasikan bahwa rumah tangga yang berpartisipasi aktif dalam kegiatan modal sosial, terutama peran dalam keuangan (misalnya yaitu rotating credit dan savings associations) memiliki beberapa keuntungan jangka panjang, seperti akses kredit dan kemampuan yang lebih baik untuk mengatasi fluktuasi pendapatan dengan meminjam atau mengumpulkan aset.

Kedua, rumah tangga penerima Program Keluarga Harapan tidak berpengaruh secara statistik terhadap modal sosial di Indonesia. Hasil temuan ini mengindikasikan bahwa rumah tangga yang menerima bantuan Program Keluarga Harapan cenderung tidak aktif atau terlibat dalam kegiatan modal sosial. Hal tersebut antara lain dapat disebabkan karena : (1) buruknya atau tidak tersedianya infrastruktur dasar seperti jalan, jembatan, listrik, dan air bersih, khususnya di daerah terpencil. Dengan demikian, upaya untuk penguatan jaringan sosial relatif rendah; (2) kurangnya dukungan mayarakat terhadap PKH; (3) lemahnya peran pendamping dalam membimbing dan mengawasi kepatuhan penerima program agar dapat bersosialisasi dengan rumah tangga lainnya; (4) adanya potensi kecemburuan dan konflik dari non-penerima bantuan $\mathrm{PKH}$, terutama di daerah desa/kelurahan dengan jumlah penerima $\mathrm{PKH}$ relatif sedikit sehingga dapat berpotensi menghancurkan ikatan sosial dalam suatu masyarakat.

Hasil penelitian ini memiliki implikasi kebijakan yang cukup penting. Modal sosial yang dimiliki oleh masyarakat tidak diragukan lagi merupakan elemen penting dalam mensukseskan program pemerintah. Dalam hal ini, adanya ikatan sosial yang kuat melalui kegiatan arisan terbukti dapat meredam gejolak akibat adanya kenaikan harga bahan bakar minyak (BBM). Selain itu, rumah tangga penerima bantuan PKH agar selalu berinteraksi (dibimbing dan dibina), melakukan pembelaan, meningkatkan hubungan masyarakat dan membangun jaringan kerja guna tercapainya keberlanjutan Program Keluarga Harapan (PKH) bagi masyarakat miskin.

\section{DAFTAR PUSTAKA}

Adato, M. .2000. Final Report: The Impact of PROGRESA on Women's Status and Intrahousehold Relations. August Report submitted to PROGRESA, Washington, DC: International Food Policy Research Institute

Aghion, P., Y. Algan, P. Cahuc, \& A. Shleifer. 2010. "Regulation and Distrust," Quarterly Journal of Economics, 125(3): 1015-1049.

Aminudin .2014. Analisis Pelaksanaan Program Keluarga Harapan (PKH) di Kota Bengkulu (Studi Kasus di Kecamatan Teluk Segara). Masters thesis, Universitas Bengkulu tidak dipublikasikan

Anderson, S., Baland, J. 2002. The economics of RoSCAs and Intrahousehold resource allocation. Quarterly Journal of Economics, 117, 963-995

Angelucci, M., \& De Giorgi, G. 2009. "Indirect Effects of an Aid Program: How do Cash Transfers Affect Ineligibles' Consumption?" AmericanEconomicReview

Attanasio, O., Pellerano, L., \& Polania, S., 2008. Building Trust: Conditional Cash Transfers and Social Capital. The Institute for Fiscal Studies

Babajanian, B. 2012. Social Pretection and Its Contribution to Social Cohesion and State Building". Eschborn GIZ: Deutsche Gesellschaft für Internationale Zusammenarbeit (GIZ) GmbH. Eschborn GIZ:

Badan Pusat Statistik. 2010. Statistik Perumahan Indonesia. Hasil Sensus Penduduk 2010

Bank Indonesia. 2005. Laporan Perekonomian Indonesia 2005. Bank Indonesia.

Bertrand, M, E. Duflo \& S. Mullainathan., 2004. How much should we trust differencesin-differences estimates. Quarterly Journal 
of Economics 119 (1), 249-275

Cameron, L., \& Shah, M., (2012) "Mistargetting of cash transfer, social capital destruction and crime in indonesia". Victoria. Monash University

Cameron, L \& Shah.,M. 2010. Scaling Up Rural Sanitation: Findings from the Impact Evaluation Baseline Survey in Indonesia. Technical report Water and Sanitation Program: Technical Paper

Coady, D., Grosh, M., \& Hoddinot, J. 2004. The Targeting of Transfers in Developing Countries: Review of Experience and Lesson. Washington, D. C: World Bank

Coleman, J. 1990. Foundations of Social Theory. Cambridge Mass: Harvard University Press.

Chong A., Ñopo H. \& Ríos V. 2009. “Do welfare programs damage interpersonal trust? Experimental evidence from representative samples for four Latin American cities". Inter American Development Bank, Research Department, Working Paper 668.

Dirjen Perlindungan dan Jaminan Sosial Kemensos. 2012, Hasil Kaji Cepat Kondisi Sosial RTSM PKH tahun 2007. Jakarta, November

Forde, I, Bell, R, Marmot, M. 2011. Using Conditionality as a Solution to the Problem of Low Uptake of Essential Services Among Disadvantaged Communities: A Social Determinants View. Am J Public Health. 2011 August; 101(8):1365-1369. doi: 10.2105/AJPH.2011.300140

Fukuyama, F. 1992. The End of History and The Last Man. New York: Free Press

Fukuyama,F.2000. SocialCapitalinH.LawrenceE., and S. P. Huntington, Cultural Matters: How Values Shape Human Progress". New York: Basic Books

Fukuyama, F. 2006. Social Capital and Society. IMF Working Paper No. 00/74
Garcia.,F, Martínez., L \& Radoselovics, J. 2006. Estimation of Social Capital in the World: Times Series by Country. Bilbao: Fundacion BBVA

Glaeser, E. L., D. Laibson \& B. Sacerdote. 2002. An Economic Approach To Social Capital. Economic Journal, v112(483,Nov), 437-458.

Glaeser, E. 2001. The Formation of Social Capital, in The Contribution of Human and Social Capital to Sustained Economic Growth and Well-Being, ed. J.F. Helliwell.

Grootaert, C. 1999. Social Capital, Household Welfare and Poverty in Indonesia. Washington: World Bank.

Hidrobo, M et al. 2012. Cash, Food, or Vouchers? Evidence from a Randomized Experiment in Northern Ecuador. IFPRI Discussion Paper 01234

Hjoullund, L., \& Svendsen, G. T. 2000. Social Capital:AStandardMethodofMeasurement. Aarhus : The Aarhus School of Business.

Hooghe, M \& Oser, J. 2015. Internet, television and social capital: the effect of 'screen time' on social capital". Taylor Francis Journal Information, Communication \& Society. Volume 18, 2015 - Issue 10

Hossain, N. 2010. School exclusion as social exclusion: The practices and effects of a conditional cash transfer programme for the poor in Bangladesh. Journal of Development Studies 46: 1264-1282.

Jordan., J.L \& Anil., B \& Munasib., A (2010). "Community Development and Local Social Capital". Journal of Agricultural and Applied Economics, 42,1(February 2010): 143-159. 2010 Southern Agricultural Economics Association

Keefer, P \& Knack, S., 2005. Social capital, social norms and the new institutional economics. In: Ménard, C., Shirley, M.M. (Eds.), Handbook of New Institutional Economics. 
Springer, New York

Kementerian Sosial Republik Indonesia. 2011. Pedoman Umum Program Keluarga Harapan tahun 2011. Jakarta: Kementerian Sosial RI, Direktorat Jaminan Sosial.

Kumlin, S, \& Bo Rothstein. 2005. Making and Breaking Social Capital. The Imp of Welfare State Institutions. Comparative Political Studies 38 (4).

Kunze, L \& Suppa, N, 2014. Unemployment and Social Participation. mimeo

Paldam, M., 2005. Social Capital And Social Policy. Arusha Conference, New Frontiers of Social Policy-December 12-15, 2005

Putnam, R.,D. 1993. The Prosperous Community: social capital and public life. The American Prospect.

Putnam, R., D., 1995 Bowling Alone: America's Declining Social Capital." .Journal of Democracy: 65. Web.

Ressler, P. 2008. The Social Impact of Cash Transfers a study of the impact of cash transfers on social networks of Kenyan households participating in cash transfer programs". International Food Policy Research Institute

Skoufias E. 2005. Progresa and its Impacts on the Welfare of Rural Households in Mexico. IFPRI Working Paper 139

Stoffler, Q., 2012. The Impact of Unconditonal Cash Transfer Programs on Farmers: Evidence From Ex-ante Simulations. Virginia: Department of Agricultural and Applied Economics

Stone, W. 2001. Measuring social capital Towards a theoretically informed measurement framework for researching social capital in family and community life. Research Paper No. 24, February 2001. Australian Institute of Family Studies

Torsvik, G., 2000. Social Capital and Economic Development. Norway; Department of Economics, University of Bergen from Department of Economics, University of Bergen

Weiss, J., 2004. Reaching the Poor with Poverty Projects: What is the Evidence on Social Returns? Asian Development Bank Institute, 2004.

Wolz., A, Fritzsch.,J \& Reinsberg., K 2005. The Impact of Social Capital on Farm and Household Income: Results of A Survey Among Individual Farmers in Poland". Paper prepared for presentation at the 94th EAAE Seminar 'From households to firms with independent legal status: the spectrum of institutional units in the development of European agriculture', Ashford (UK), 9-10 April 2005

Woolcock, M. 1998. Social Capital and Economic Development: Toward a Theoretical Synthesis and Policy Framework. Theory and Society, 27 (1),151-208. In Elinor Ostrom and T.K. Ahn. 2003. Foundation of Social Capital. Massachusetts: Edward Elgar Publishing Limited.

Van Ingen, E \& Van Eijck .2009. Leisure and Social Capital: An Analysis of Types of Company and Activities. Taylor Francis Online Journal Vol. 31

Varadharajan., S 2004. Explaining Participation in Rotating Savings and Credit Associations (RoSCAs): Evidence from Indonesia. Department of Economics. Cornell University Ithaca, NY 14853 